\title{
Urban Slum Characteristics in the Niger Delta Region of Nigeria: Imperatives for improvement
}

\author{
Abotutu Ahi Abel \\ Department of Geography and Regional Planning, Delta State University, P.M.B 1, Abraka-Nigeria
}

\begin{abstract}
Problems of urban environmental degradation and inadequacy of housing and basic infrastructural facilities in the Niger Delta cities are well known. The discovery of petroleum oil in the Niger Delta region in the 1950s, is particularly remarkable for very rapid growth of the population of the region, which has increased and greatly intensified problems arising from the inadequacy of urban infrastructural facilities. The rapidity of overall population growth arises from a combination of a high rate of natural increase and a much higher rate of migration. This paper attempts an empirical analysis of slum characteristics in four leading cities in the Niger Delta region, Nigeria. Findings reveal that slum dwellers in these four cities live in subhuman conditionssubstandard dwelling units and protracted lack of community amenities and services. "Upgrading" rather than "clearance", among others, were recommended for sustainable management of slum areas in the Niger Delta cities in particular and Nigerian cities in general.
\end{abstract}

Keywords: Urban, slum, characteristics, Nigeria, improvement.

\section{Introduction}

The most degraded environment in Nigeria is found in the Niger Delta region. Located in the central part of southern Nigeria, the Niger Delta is Africa's largest delta covering some 70,000 square kilometers and encompassing nine states of the federation, namely Akwa-lbom, Bayelsa, Cross River, Delta, Edo, Rivers, Abia, Imo and Ondo (World Bank, 1996; International Crisis Group, 2006). About one third of the region is made up of wetlands, and it contains the third largest mangrove forest in the world. It is also home to Nigeria's oil industry. The country is the largest producer of petroleum products in Africa, and among the world top ten, and almost all its production comes from the Niger Delta region (UNDP, 2006; Umukoro,2010).

The inhabitants in the region bear the brunt of the environmental impact of oil production and pollution from other human activities which include fishing, agriculture, forest resource exploitation and demographic change. Concern has been growing over this region both nationally and internationally. In spite of the delta's resource endowment and its immense potential for economic growth and sustainable development, it is under increasing threat from rapidly deteriorating physical and social environments which are not being addressed by current policies and behavior patterns. A study of the region by the World Bank (1996) has warned that "an urgent need exists to implement mechanisms to protect the life and health of the region's inhabitants and its ecological systems from further deterioration".

The government's response to the state of affairs in the Niger Delta region in this regard has been typical. Development boards, including the Niger Delta Development Board (NDDB), the Oil Minerals Producing Areas Development Commission (OMPADEC) and, most recently, the Niger Delta Development Commission (NDDC) have been set up at different times to "speedily develop the region". These extraministerial institutions were given the specific task of promoting the development of the region. For example the mandate of the OMPADEC includes the rehabilitation and development of oil-producing communities, tackling ecological problems arising from petroleum pollution, and the provision of basic infrastructure and social amenities (OMPADEC, 1993). The NDDC has similar functions, in addition to the formulation of policies and guidelines for the development of the region, and the identification of factors inhibiting the development of the area (NDDC Act, 2006).

Hitherto, evidence in the region supports the assertion that none of these organizations has achieved its core targets. If anything, the general situation in the region worsened because inhabitants of the area became further frustrated with the ineptitude of the organizations that were established primarily to better their lives (Afeikhena, 2005; Ahmed-Hamid, 2006; Torulagha, 2007; Aboribo and Umukoro, 2008; Ojakorotu, 2008; Yesuf, 2008).

The need to ascertain the living conditions of urban dwellers in the Niger Delta region provided the impetus for this paper which attempts an empirical verification of slum characteristics in four leading cities in the Niger Delta region of Nigeria, for the benefit of public policy. 


\section{Statement of the Problem}

There will be about 50 million people living in the Niger Delta region by the year 2020 and as many as 60 per cent of them may be urban dwellers if the present rate of urbanization continues. It is unlikely that the present trend of increasing urban population growth in the Niger Delta region can be changed for some time to come. This is because for many Nigerians there is the belief that the only hope of improving their standard of living is to live in an urban environment. One major challenge of urban population growth in the Niger Delta region in the new millennium is the need to provide a tolerable urban environment for the increasing agglomeration of people in towns and cities of the region. This challenge is bound to increase in the coming decades due to the expected rise in urban population. With about half of the inhabitants of the Niger Delta region living in urban centres, there is no doubt that the task of providing a tolerable urban environment is indeed staggering. In addition, there will be need to make up for past and existing deficiencies in urban environments. At the same time policy makers, planners, researchers and the general public in recent years have shown concern over the existing and deteriorating environmental situations in the Niger Delta cities. It is being increasing realized that the quality of the environment in which urban dwellers in the Niger Delta live is an integral part of the overall indicators of development. A city's natural environment by itself does not determine the quality of urban life. However, the ways in which people perceive the natural environment of their city and develop and use it will reflect much about the quality of life (Onokerhoraye, 1976).

It is against this background of increasing urbanization in the Niger Delta region, coupled with its implications for the environment in which urban dwellers live, as well as the growing concern for the need to ensure a tolerable urban environment in the area that this paper presents case studies of slum areas in four leading cities in the Niger Delta region of Nigeria. The paper attempts an empirical verification of the main physical characteristics of selected slum areas in four cities in the Niger Delta region of Nigeria. The next section of the paper presents a general discussion on the various perspectives on the nature of slums. This is followed by discussion of the data obtained from the four slum areas in Benin (Edo State), Akure (Ondo State), Warri (Delta State) and Port Harcourt (River State). Finally, the discussion of the policy implications of the existing physical structure of slum areas in cities of the Niger Delta region in particular and Nigeria in general, is presented.

\section{Perspectives on Slum}

There is no single and accepted definition of what a slum area is. There are various definitions which reflect the different orientations of various disciplines, such as sociology, demography, economics, medicine and physical planning. At the same time, different societies define slums in different ways, even among people in the same discipline. Thus, the physical planners' definition of a slum in the United States of America or Great Britain is bound to be different from that of a developing country such as Nigeria. This is a reflection of the varying levels of socio-economic development which characterizes different countries in the world.

Despite this lack of agreement, an attempt can be made to provide an overview of what constitutes a slum area in the context of Third World countries in general and Nigeria in particular. Third World cities are known to have two types of environmentally degraded areas. The first is the "squatter settlement" which comprises uncontrolled or temporary dwellings largely inhabited by migrants from outside the city concerned. Often, such areas are occupied illegally since building plans are not approved before dwellings are built. The second type is the "slum proper" which can be defined as legal, permanent dwellings which have become substandard through age, neglect/and or subdivision into micro-occupational units such as rooms, cubicles or cocklofts (Drakakis-Smith, 1981).

As noted earlier, there are different perspectives on the nature of slums. Most contemporary attitudes and interpretations of the nature and origin of slums are derived from the Victorian era. During the Victorian period, slum dwellers were viewed as a socio-spatially isolated group whose separation was attributed variously to preferred deviance, the rejection of the work ethic, and other anti-social values. In other words, slum areas have traditionally been viewed as generators of a host of deviant behaviour such as criminality, prostitution and juvenile delinquency. The theoretical foundation for this social perspective on slum areas can be traced back to the works of the Chicago School of Social Ecologists in the 1920s, especially those of Mckenzie, Park and Burgess. The basic tenets of their works involved an attempt to explain social behavior in terms of environmental determinism. Thus, the zones of deterioration which are largely slum dwelling areas were summarily regarded as generators of social deviation (Odongo, 1979).

In Third World countries, studies of slums as a social problem have, in general, tended to follow the theoretical path established by Burgess and his colleagues. Reviewing studies carried out in Ghana, Uganda, the Philippines and Venezuela, among other developing countries, Clinard and Abbot (1973) have noted a significant degree of correlation between slum housing and deviant behavior.

Economically, slum areas are viewed as areas Inhabited by the poor in the urban system. The economic perception of slum areas is thus largely that of a people who are unskilled and therefore cannot be 
employed. Since there is no employment, there is no source of income for the vast majority of the dwellers of slum areas. Thus, Portes (1971), in a not untypical passage has described urban slums in Chile as housing the poorest of the poor - the unemployed, the unskilled, and illiterate and often the alcoholic, the vagabond, and the delinquent. According to Portes, the slum and its inhabitants have both reached dead-end situations - a refuge of ultimate destitution.

Following from the economic and social perspectives on slum areas as outlined above, there is the political perspective which views slum areas as the breeding ground of political radicalism and violence. This perspective stems from the basic assumption that slum dwellers' experiences of poor living conditions and a variety of socio-economic hardships would, in time, generate feelings of frustration and discontent. Such feelings would eventually lead to an eruption of political radicalism and violence (Portes, 1971).

Finally, the environmental implication of the social, economic and political perspectives of slum areas is the emergence of decayed physical environments. Overcrowding is a demographic phenomenon which occurs indiscriminately in slums. Overcrowding is generally regarded as a hazard to health and, in particular, encourages the spread of infectious diseases, such as typhoid and tuberculosis. This is most pronounced in a residential situation in which sleeping accommodation is congested and the ventilation facilities poor. Thus, the theory that a filthy and decaying environment is indeed a health hazard of slum dwellers is widespread (Abrams, 1966; Clinard, 1966). Clinard, in a study of slums in India, and Marris (1961) in Lagos, for example, have independently observed that the often supposed poor health of slum dwellers is not exclusively a consequence of poor housing conditions as such, as poor health could also be attributed to unbalanced diet, inadequate medical facilities and wilful disregard of personal hygiene.

The preceding perspectives on the nature of slums can be broadly described as dysfunctional perceptions of slum areas which, as noted earlier, is derived from the Victorian era. However, in recent years, a number of researchers have, in opposition to the dysfunctionalists, put forward a case in defence of slum housing. The common solution prescribed by the dysfunctionalists to slum dwellings is clearance or redevelopment. In contrast, the functionalists' arguments have, in the main, revolved around the notion that, as a pragmatic solution to the mounting problem of housing shortage, slums ought to be preserved and improved rather than eradicated (Casasco, 1969). They have sought to highlight the value of slum housing from both sociological and economic perspectives. Their argument from a sociological perspective rests on the premise that slums are an asset in the sense that they perform acculturating and transit-oriented functions for urban immigrants. From an economic perspective, the functionalists have argued a case for the value of slums. It is a variant of the argument which draws upon the general theory of urban employment structure and income flow patterns. Thus, the argument is advanced that slums usually offer a wide range of employment as well as investment opportunities for low-income groups. In other words, slums are viewed as contributing to capital formation, as demanding imports from the urban centre, and as supplying important quantities of unskilled and semi-skilled labour to the urban centre. The functionalists appear to find it rather difficult to adduce good physical values to the slum housing areas in the cities. They appear to agree with the dysfunctionalists on this issue.

In Nigeria, interdisciplinary studies of slum areas are very limited. With the exception of Marris' study, almost 50 years ago no other sociological studies have been undertaken of slum areas in Nigerian cities. Similarly, economists, political scientists, demographers and health engineers and community health experts have not paid much attention to the study of slums in Nigeria. It is geographers alone that have, in recent years, paid considerable attention to the study of the physical aspects of slums. Even urban planners who could have complemented the work of geographers have not done much work in this area.

\section{Methodology}

The data analyzed in this section is derived from the survey of four slum areas selected from Benin, Akure, Port Harcourt and Warri. The survey was conducted by the Niger Delta Development Commission (NDDC) in 2013. No effort was made during the survey to analyse all the slum areas in the four towns noted above. Consequently, no rigorous definition and identification of slum areas was attempted. The selected slum area in each urban centre was made after a thorough reconnaissance survey of all the worst residential areas with respect to their physical characteristics. In Warri, a section of Okere was selected and five hundred houses and households were randomly selected for the survey. In Akure, a section of Elekuro was selected and five hundred houses and households were surveyed. In Benin, a section of the central areas, around Ibiwe was selected and four hundred houses and households were surveyed. And finally in Port Harcourt, Choba residential area was selected and four hundred houses and households were surveyed. The questionnaire administered focused on the social, economic and physical characteristics of the households and dwellings in which the inhabitants live. However, the analysis here focuses on the physical characteristics of the dwellings and the overall environment in which they are located. 


\section{Location and Land-Use Pattern}

The location of the selected slum areas in the four cities indicates that slum localities in Nigerian cities can be found in any part of urban areas. This is a reflection of the origin of the slum concerned. The slum areas selected from Benin and Akure are located in the central areas of these cities, while that selected from Port Harcourt is located midway between the city centre and the suburb. In Warri, the selected slum area is located in the suburb.

The slum areas in Benin and Akure are good examples of traditional slums which are made up of residential areas built up during the pre-colonial era or during the early years of colonial administration in Nigeria. Apart from the poor building materials and low technology which gave birth to such slum areas, lack of development control contributed remarkably to their emergence. On the other hand, the slum area in Port Harcourt presents as example of a slum which developed as a result of the expansion of the continuously builtup urban area into existing rural villages. Since such villages were not planned and the houses built of local materials to house mainly farmers, the physical environment of these areas contrast sharply with that of the surrounding urban neighborhoods. The subsequent expansion of the continuously built-up urban area eventually places such slum areas between the city centre and the suburb. Finally, the selected slum area of Warri owes its origin to the squatting of urban dwellers who could not find or afford accommodation in the city proper. Such localities where makeshift dwellings are constructed develop into slums. Since these slums areas are located outside the defined city boundary, land use development is not subjected to any form of control by planning authorities.

One of the major factors which contribute to the overall quality of the physical environment of any locality within an urban area is the allocation of land to various land use types. The field survey in the selected slum areas indicates that residential dwellings constitute over 80 per cent of the total developed land in them. Table 1 indicates that the selected slum area in Akure had about 90 per cent of the total developed land devoted to residential land use. The figures for Warri and Port Harcourt slum areas are a little lower, which suggests that modern slums in the cities of the country tend to have a lower proportion of their land use devoted to residential areas. However, the slum areas in Benin which, like those in Akure are traditional, have the lowest figures. This can be explained by the traditional system of building in Benin. The large compound dwelling which characterizes traditional Yoruba towns is not common in Benin (Sada, 1979). Rather, there are small detached buildings owned by one nuclear family. Consequently, the density of residential dwellings is lower as some space is left between individual buildings. In all the slum areas, the proportion of land devoted to residential areas is excessive when it is realized that ideally only about 50 to 60 per cent of the developed land in high density residential areas of Nigerian cities should be devoted to residential dwellings.

Another serious defect of the land use structure in the selected slums is the small amount of land devoted to transport, that is, roads and streets. Ideally, high density residential areas, to which the slum areas belong, should devote between 15 and 20 per cent of the land area to circulation. Table 1, indicates that the slum areas in Port Harcourt, Akure and Warri have less than 10 per cent of the developed land devoted to roads and streets. This indicates that mobility within the slum areas is highly restricted. The table again indicates that the selected slum area in Benin City is better off compared with others because it has over 12 per cent of the developed land devoted to roads and streets. This can be explained by the fact that Benin, unlike many other traditional Nigerian cities, has a relatively good town plan. Thus, the traditional residential neighbourhoods which constitute the bulk of the slum areas in the town do have a reasonable network of roads and streets.

Table 1

Land Use Structure in Selected Slum Areas (\% of Total)

$\begin{array}{lrrrr}\text { Land Use Type } & \text { Port Harcourt } & \text { Akure } & \text { Benin } & \text { Warri } \\ \text { Residential } & 84.5 & 89.2 & 81.5 & 85.5 \\ \text { Industrial } & 5.2 & 1.0 & 1.5 & 0.0 \\ \text { Commercial } & 2.5 & 3.8 & 2.5 & 1.0 \\ \text { Public } & 0.2 & 0.0 & 0.0 & 1.5 \\ \text { Semi-Public } & 1.6 & 2.0 & 2.0 & 2.0 \\ \text { Transport } & 5.0 & 4.0 & 12.5 & 8.2 \\ \text { Recreation and open space } & 0.0 & 0.0 & 0.0 & 0.0 \\ \text { Others } & 1.0 & 0.0 & 0.0 & 1.8 \\ \text { Total } & \mathbf{1 0 0 . 0} & \mathbf{1 0 0 . 0} & \mathbf{1 0 0 . 0} & \mathbf{1 0 0 . 0}\end{array}$

Source: NDDC Field Survey, 2013. 
Finally, Table 1 indicates vividly that a very insignificant proportion of land in the selected slum areas of the four towns is devoted to commercial and other land use types. This indicates that community services whenever they exist in the slum areas do not have adequate space. In fact, recreational space is non-existent in all the selected slum areas.

One implication of the almost complete allocation of developed land in the selected slum areas in Nigerian cities is the high population density per hectare in the areas. The field survey indicates that the densities range from 600 persons per hectare in Warri to 1,500 persons per hectare in Akure. Port Harcourt and Benin slum areas have densities of 1,200 and 1,000 persons per hectare, respectively. These high densities contrast with the normal standard of between 100 and 200 persons per hectare which is acceptable in high density residential areas of Nigerian cities. The high densities therefore constitute serious constraints on the maintenance of an acceptable standard of environmental sanitation in these areas.

Some explanations for the preceding pattern of land use identified in the selected slum areas of Warri, Benin, Akure and Port Harcourt can be suggested. In the first place, a large proportion of the inhabitants of these areas belong to the lower socio-economic activities, while a significant proportion are unemployed. Secondly, the development of the selected slum areas has not been carried out under the supervision of planning authorities. Finally, the attitude of some of the dwellers towards the development of their environment has not been positive, particularly in those slum areas where a significant proportion of the inhabitants are migrants.

\section{Housing Characteristics}

The field survey of the housing characteristics in the selected slum areas of Warri, Akure, Benin and Port Harcourt indicates marked variations in terms of housing conditions. Table 2 attempt to measure the degree of overcrowding in the selected areas. Nigerian planning standards for urban areas indicate that the average number of rooms per household should be three. However, Table 2 shows that the majority of the households in the surveyed areas of Warri live in one or two rooms. The situation in Port Harcourt is essentially similar. In these two cities, only a few of the households live in three or four rooms. On the other hand, in Akure and Benin City, there appears to be a relatively even distribution of households among the three categories. This suggests that in the traditional slum areas, the pressure of accommodation space is not as serious as in the modern ones. One explanation for this is that a growing proportion of the young generation now moves out of these traditional areas to build modern houses in the outskirts of the cities. As a result, it is only those who cannot afford to build modern houses in localities of those cities where development control is quite effective that are left behind, thereby reducing the pressure on accommodation.

The number of room per household as an indicator of the pressure on accommodation is not adequate because it does not take into consideration the size of the households concerned. Consequently, the usual indicator of overcrowding is the number of persons per habitable room. Table 2 presents the pattern in the selected areas. It indicates that in all four cities, over 50 per cent of the dwellings surveyed have three or four persons per room. This is against the average national standard of two persons per room in the urban areas. One would have expected that the figures for Akure and Benin would be better than those of Warri and Port Harcourt considering the fact that it was observed in the preceding paragraph that the average number of rooms per household was higher in the former. The reason for the existing pattern is that household sizes are large in the traditional slum areas where most of the inhabitants are indigenes of the town concerned and where family planning is not yet popular. With large households, the pressure on available rooms is bound to be high no matter their number.

Table 2

Average Number of Rooms Per Household / Occupancy Ratio Per Room in Selected Slum Areas

(\% of Total)

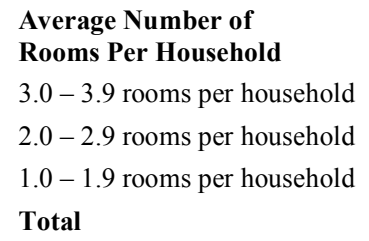

Source: NDDC Field Survey, 2013.

$\begin{array}{crrr}\begin{array}{c}\text { (\% of Total) } \\ \text { Port } \\ \text { Harcourt }\end{array} & \text { Akure } & \text { Benin } & \text { Warri } \\ 14.0 & 35.2 & 35.5 & 15.6 \\ 34.5 & 32.8 & 28.5 & 35.4 \\ 51.5 & 32.0 & 36.0 & 49.0 \\ \mathbf{1 0 0 . 0} & \mathbf{1 0 0 . 0} & \mathbf{1 0 0 . 0} & \mathbf{1 0 0 . 0} \\ & & & \\ & & & \\ 13.0 & 11.0 & 19.8 & 19.0 \\ 25.5 & 31.5 & 28.2 & 21.6 \\ 61.5 & 57.5 & 52.0 & 59.4 \\ \mathbf{1 0 0 . 0} & \mathbf{1 0 0 . 0} & \mathbf{1 0 0 . 0} & \mathbf{1 0 0 . 0}\end{array}$


It should be noted, however, that the use of a person's-per-room ratio as an indicator of overcrowding has some problems which detract from its usefulness as the most realistic measure of the pressure on accommodation. In the first place, the indicator ignores the area and volume of the room. Secondly, it fails to distinguish between adults and children occupants. Thirdly, it does not take into consideration outdoor living space which could be quite important. Despite these problems, the indicator can provide a useful comparison of overcrowding in different parts of one or more urban areas. It is in this context that this indicator is used in this study.

Another housing characteristic which is of relevance to our purpose in this paper concerns the physical features of the dwellings themselves. Table 3 indicates five main combinations of building materials that could be used in the selected areas. It shows that in Akure and Benin, the vast majority of the dwellings are built of mud walls with galvanized or asbestos roofs. In these two cities only a few of the dwellings in the selected areas have cement-rendered mud walls, while less than 3 per cent are built of sand-crete block walls. This pattern again reflects the traditional nature of the dwellings. Most of the inhabitants built their houses during the precolonial or early colonial period with the local materials they could lay hands upon. The situation in Port Harcourt and Warri is different in the sense that, in the former, makeshift wooden walls constitute about 20 per cent of the dwellings while, in the latter, mud walls with thatch roofs are also important.

An analysis of the age structure of the dwelling units surveyed also indicates marked differences between those located in the selected areas of Warri and Port Harcourt, on the one hand, and Akure and Benin, on the other. Table 3 shows that in Warri, over 50 per cent of the dwellings are either ten or less years. In Port Harcourt, most of the dwellings are between eleven and thirty years. This pattern contrasts with the situation in Akure and Benin where the majority of the buildings are over 30 years. The relatively young age of the dwellings in the Warri area can be explained by the fact that the selected area is a suburb where many recent migrants to the city have concentrated. In Port Harcourt, the relatively old age of some of the dwellings is because such buildings were in existence as rural settlements before the town intruded and many newer buildings were added.

Table 3

Construction Materials/Age Structure of Dwelling Units in Selected Slum Areas

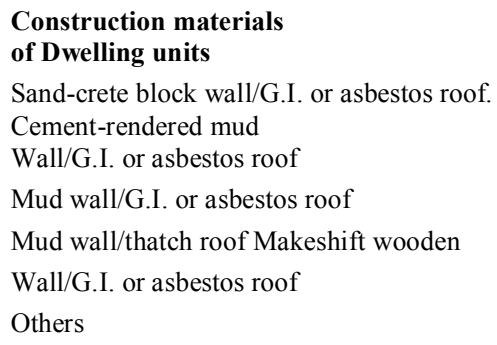

Houses located in the slum areas of Nigerian cities are known to be poorly ventilated. The survey indicates that there are many rooms in the dwellings, particularly in Akure, Benin and Warri which do not even have one window. The vast majority of the rooms in the dwellings have one or two small windows (Table 4). The survey also attempted to examine the maintenance of the dwellings in the selected areas. Table 4 indicates that most of the dwellings are not effectively maintained. Consequently, most of them require major repairs. The table also indicates that a significant proportion of the dwellings in the selected areas in Akure, Benin and Warri are in a deteriorating condition. A few other houses are in dilapidated conditions. 


\section{Housing Facilities}

The survey attempted to examine the nature of basic facilities available in the dwellings of the selected areas by investigating the availability or otherwise of certain basic facilities which are essential for a healthy residential environment. Table 4 indicates that about 40 per cent of the dwellings in the selected areas of the four cities had no kitchen, toilet or bathroom. It also indicates that only about 10 per cent of the dwellings have the three facilities. The remaining dwellings have a combination of only two of them.

An analysis of the type of sewage facilities used in those dwellings with any facilities indicates that in all the selected areas, the pit latrine is the commonest form of sewage disposal facilities. The septic tank accounts for less than 10 per cent of the dwellings which have sewage disposal facilities. The pail collection system is still quite common in Warri while it is of less significance in Akure, Benin and Port Harcourt (see Table 4). The nature of water supply available in the selected areas varies from one city to the other (Table 4). In Warri, wells with untreated water provide the dominant source of water supply to the dwellings. In Akure and Benin, public taps provide water for most dwellings. In Port Harcourt, the river is the main source of water for most of the dwellings. The main trend in all the areas is that pipe-borne water connected to individual dwellings is not common. As a result, most of the inhabitants have to use jerry cans to search for and collect water for their daily needs.

Table 4

Ventilation, Structural Stability, Interior Facilities, Sewage Disposal Facilities, Access to Water Supply and Refuse Collection Points of dwellings in

Selected Slum Areas

(\% of Total)

Ventilation

Rooms without windows

Rooms with one windows

Rooms with two windows

Rooms with three or four windows

Rooms with more than four windows

Total

Structural Stability

Sound (Needs no maintenance)

Needs minor repairs

Needs major repairs

Deteriorating

Dilapidated

Total

Interior Facilities

Has kitchen, toilet and bathroom

Has kitchen and toilets

Has kitchen and bathroom

Has toilet and bathroom

Has no kitchen, toilet and bathroom

Total

Harcourt
19.8
20.2
41.0
10.0
9.0
$\mathbf{1 0 0 . 0}$

100.0

Sewage Disposal

Septic tank

Pit latrine

Free range defication

Others

Total

Water Supply

Pipe-borne water

connected to dwelling

Public taps

Well

Rivers

Others

Total

$\begin{array}{rrr}\text { Akure } & \text { Benin } & \text { Warri } \\ 32.0 & 28.0 & 25.2 \\ 35.4 & 29.4 & 31.8 \\ 25.6 & 31.5 & 20.0 \\ 6.0 & 7.1 & 12.5 \\ 1.0 & 4.0 & 10.5 \\ \mathbf{1 0 0 . 0} & \mathbf{1 0 0 . 0} & \mathbf{1 0 0 . 0}\end{array}$

$\begin{array}{rrr}5.6 & 8.8 & 10.7 \\ 30.2 & 27.6 & 21.3 \\ 34.8 & 42.7 & 38.0 \\ 21.4 & 15.9 & 23.0 \\ 8.0 & 5.4 & 7.0 \\ \mathbf{1 0 0 . 0} & \mathbf{1 0 0 . 0} & \mathbf{1 0 0 . 0}\end{array}$




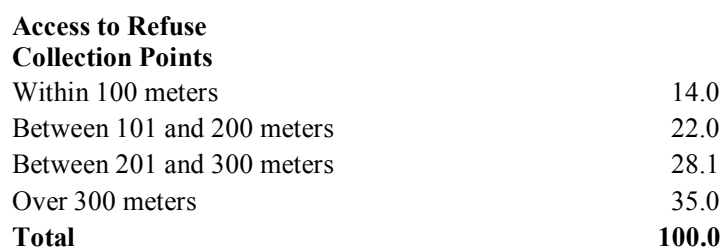

$\begin{array}{rrrr}14.0 & 7.0 & 20.2 & 21.9 \\ 22.0 & 19.6 & 21.8 & 21.4 \\ 28.1 & 31.4 & 28.9 & 25.2 \\ 35.0 & 42.0 & 29.1 & 31.5 \\ \mathbf{1 0 0 . 0} & \mathbf{1 0 0 . 0} & \mathbf{1 0 0 . 0} & \mathbf{1 0 0 . 0}\end{array}$

Source: NDDC Field Survey, 2013.

\section{Availability of Community Services}

Field work and data mapping in the selected slum areas indicate that the areas are largely neglected in terms of the provision of community services. Table 4 indicates that most of the dwellings in the various slum areas do not have easy accessibility to refuse collection points. The table shows that in Akure, only 7 per cent of the dwelling units are within 100 meters of the nearest refuse collection points. The percentages for Warri, Benin and Port Harcourt are comparatively higher. However, about 30 per cent or more of the dwelling units in the selected areas of the four cities are in locations which are more than 300 meters from the nearest refuse collection points. One of the major factors responsible for the long distance which households in these areas have to walk before getting to the nearest refuse collection points is the lack of motorable roads in Warri, Port Harcourt and Benin (see Table 5). Finally, Table 5 indicates that most pupils in the slum areas of the four cities walk longer distances before getting to a primary school which, in most cases is located far away from them. Lack of space for the location of a school is largely responsible for this.

Table 5

Accessibility of Dwelling Units to Motorable Roads and Primary Schools in Selected Slum Areas

(\% of Total)

Accessibility to Motorable Roads

Within 50 meters

Between 51 and 100 meters

Between 101 and 150 meters

Between 151 and 200 meters

Over 200 meters

Total

$\begin{array}{lr}\begin{array}{c}\text { Port } \\ \text { Harcourt }\end{array} & \text { Akure } \\ 10.0 & 13.0 \\ 25.0 & 15.0 \\ 29.0 & 27.3 \\ 31.4 & 19.5 \\ 4.6 & 25.2 \\ \mathbf{1 0 0 . 0} & \mathbf{1 0 0 . 0}\end{array}$

$\begin{array}{rr}\text { Benin } & \text { Warri } \\ 55.8 & 24.0 \\ 25.2 & 45.0 \\ 15.0 & 19.5 \\ 4.0 & 10.0 \\ 0.0 & 1.5 \\ \mathbf{1 0 0 . 0} & \mathbf{1 0 0 . 0}\end{array}$

Accessibility to Primary Schools

Less than $1 \mathrm{~km}$

0.0

15.2

20.5

Between $3.1 \mathrm{~km}$ and $5.0 \mathrm{~km}$

64.3

Above $5 \mathrm{~km}$

Total

100.0
00.0

Source: NDDC Field Survey, 2013.

\section{Conclusion and Policy Implications}

Comprehensive policy implications of the physical characteristics of the selected slum areas in Nigerian cities cannot be provided until the overall social, economic, political and demographic characteristics of these areas are analysed. However, on the basis of results of the survey coupled with other studies of the physical environment of Nigerian cities, some policy issues can be identified. These policies can be divided into two categories. In the first category, are long-term policy issues relating to the prevention of slum areas in Nigerian cities.

One of the issues in the first category relates to the reduction of the rate of urban population growth. It is inevitable that a reduction in fertility is a necessary condition for solving the population - resource pressures of the urban centres of Nigeria. This suggests that the means for affecting such a reduction become an issue of transcendent importance. Generally, the only proved method for inducing a lasting and significant lowering of the birth rate has been to raise substantially a population's level of living, and aspiration for further gains.

However, this process is difficult to initiate; it requires the generation and input of considerable capital and consumes much valuable time. This time lag is a significant one, for not only does it take a number of years to push a population upwards to a higher socio-economic stage, but there is also a further, roughly equivalent period before the new fertility pattern reflects this achievement. In Nigeria, particularly in the urban areas, there 
is an immediate need to retard population growth substantially by perfecting the implementation of family planning programmes and to consider even more direct and effective measures.

As regards the control of rural-urban migration, it is obvious that the rate of rural-urban migration will continue to increase in Nigeria except an effort is made to improve conditions in the rural areas. Since one of the factors impelling young rural inhabitants to move to the urban areas is resentment of the traditional system of social and economic control exerted by the family and village elders, the provision of independent economic opportunities which are not subject to the control of the elders will reduce feelings of resentment towards them. In this respect, a programme of integrated rural development should be adopted and implemented. Two major issues should be emphasized in any programme of integrated rural development in Nigeria during the coming decades. The first relates to the importance of encouraging the development of medium-size towns in rural areas to facilitate the distribution of social amenities to rural dwellers. A second policy issue in integrated rural development in Nigeria relates to the need of improving the income of rural dwellers through major investments in agricultural modernization, including mechanization, cooperative land tenure reforms, the provision of credit facilities to farmers, and use of fertilizers.

Another long-term policy issue relates to the generation of urban employment opportunities. The quality of life and urban environment cannot be significantly improved in Nigerian cities without increasing employment opportunities for urban dwellers. Measures which could help to accomplish this objective can be envisaged, but problems of application in practice are significantly more complex. The difficulties arise when an attempt is made to strike a balance between what is possible in the short run, and what may be desirable in a long-term employment policy. The best conceived combination of measures is subject to what the actual decision makers deem to be viable in accordance with local socio-political realities. Employment policy measures usually demand extensive structural adjustments, such as agrarian reform, more appropriate production techniques, a transformed educational structure, modifications in labour legislation, and policies to deal with population and migration issues. Three areas where public policy must focus attention in the coming decades relates to industrial development, infrastructural development, and the informal sector.

It is obvious that if the manufacturing sector of the urban economies in Nigeria is to be expanded in a way to provide employment opportunities for absorbing large numbers of unemployed people, the existing system of fiscal incentives should be modified and new ones introduced to make the system more relevant to the employment situation in the urban areas. in this connection, the direction of policy should be towards fiscal measures which will encourage a greater utilization of labour. In other words, policy-makers should strive to encourage a complete shift from the existing highly capital-intensive technologies to more labour-intensive methods of production in the manufacturing sector. One way by which existing tax incentives can be modified is to link them up specifically with employment targets. As far as urban infrastructural development is concerned, one of the most effective policies to reduce significantly the rate of under-employment is the implementation of urban infrastructural projects. Such a policy fits in with the emphasis on the need for upgrading urban infrastructure in Nigeria's national development programme. Public sector investment can play an increasingly important role in labour absorption by creating new jobs in transport, urban services and communications. In terms of the utilization of investment resources, appropriate policies are needed to minimize the lag between the approval and the implementation of projects. One obvious recommendation is to encourage the use of more labour-intensive techniques where feasible. Finally, the informal sector of Nigerian urban economies needs some attention so that the sector can make a positive contribution to employment generation. In order to be able to meet the future demand for greater productivity, the informal sector requires assistance in fostering and developing its apparent dynamism. There is a greater need to collect information and to learn about the informal sector's problems without this it will not be possible to suggest meaningful policies to promote employment and labour productivity in the informal sector of Nigerian cities.

As far as short-term selections are concerned, these relate largely to a programme of selective development of the slum areas. A large proportion of the housing in the identified slum areas can be improved by re-roofing, enlarging windows, painting, landscaping and introducing better air circulation and sanitation. The worst parts of the slum areas could be cleared to provide space for roads, schools, open spaces, etc. A programme of total clearance is expensive and it is not likely to be effective as the Lagos experience of the 1960s indicates. 


\section{References}

[1]. Aboribo, R.O. and Umukoro, N. (2008) "Conflict of Globalization and the Globalization of Niger Delta Conflict", Nigerian Sociological Review, Vol.8.

[2]. Abrams, C. (1996). Squatter Settlements: the Problem and Opportunities, Washington, D. C.: Division of International Affairs, Department of Housing and Urban Development.

[3]. Afeikhena, J. (2005) "Managing Oil Rent for Sustainable Development and Poverty Reduction in Africa", UNWIDER Jubilee Conference 2005, available at http://www.wider.unu.edu/conference/conference-2005-3/conference-2005.htm.

[4]. Ahmed-Hammed, A. (2006) "The Implications of Rising Oil Prices and Environmental Concerns for Oil Exporting Countries", Nigerian Journal of International Affairs, Vol. 32, No.2.

[5]. Casasco, J. A. (1969). "The Social Function of Slums in Latin America: Some Positive Aspects", American Latin, vol. 16, pp. 87111.

[6]. Clinard, M. B. and Abbott, D. J. (1973). Crime in Developing Countries: a Comparative Perspective, New York: Wiley.

[7]. Clinard, M.B. (1966). Slums and Community Development: Experiments in Self-help, New York: Free Press.

[8]. Drakakis-Smith, D.W. (1973). "Urban Planning Problems in South-east Asia" in G. Seddon (ed.), Urbanization: Twelve papers delivered at the ANZAAS Congress,_University of Melbourne.

[9]. International Crisis Group (ICG)(2006) "Nigeria: Seizing the Moment in the Niger Delta", Africa Briefing No. 60, 30, April.

[10]. Marris, P. (1961), Slum Clearance and Family Life in Lagos, London University Press.

[11]. Niger Delta Development Commission (NDDC) Act (2000).

[12]. Odongo, J. (1979). “Housing Deficit in Cities of the Third World: Fact or Fiction?' in H.S. Murison and J.P. Lea (eds.) Housing in Third World Countries, pp. 31-42.

[13]. Oil Mineral Producing Areas Development Commission (OMPADEC) Act (1993).

[14]. Ojakorotu, V. (2008) "The Internationalization of Oil Violence in the Niger Delta of Nigeria", In Alternatives, Turkish Journal of International Relations, Vol.7 (1) Spring.

[15]. Onokerhoraye, A.G. (1976). "Urban Environmental Problems and Planning Strategies in Tropical Africa: The Example of Nigeria", The Annals of Regional Science, vol. 10, pp. 24-35.

[16]. Portes, A. (1971). "The Urban Slum in Chile: Types and Correlates", Land Economies, vol. 47, pp. $697-720$.

[17]. Sada, P.O. (1979). "The Rural-Urban Fringe of Warri: Population and Land Use", The Nigerian Journal of Economic and Social Studies, vol. 12, pp. 225-41.

[18]. Torulagha, P. S. (2007) "The Niger Delta, Oil and Western Strategic Interests: The Need for Understanding", http//unitedijawstates.com. accessed June 28, 2007.

[19]. Umukoro, N. (2010) "Beyond Amnesty: Gurbing the Looming Civil War and Environmental Scarcity in Nigeria's Niger Delta", A Paper Presented at the International Conference on the Territorial Origins of African Civil Conflicts, Organized by Ohio State University, USA and the University of Kwazulu Natal, South Africa in Pietermarizburg, South Africa, January $29^{\text {th }}$ and $30^{\text {th }} 2010$.

[20]. UNDP (2006) Niger Delta Human Development Report, Abuja: UN House, p.15.

[21]. World Bank (1996) "Nigeria: Poverty in the Midst of Plenty; The Challenge of Growth Inclusion, Washington D. C., World Bank.

[22]. Yusuf, H. O. (2008) "Oil on Troubled Waters-Multinational Corporations and Realizing Human Rights in the Developing World with Particular Reference to Nigeria", African Human Rights Law Journals (8)(1). 